\section{Dental calculus}

\section{G. H. Sperber of the University of Alberta, Canada muses on a substance that endures long past its owner.}

A part from the mathematical calculations required to run a modern dental practice, dental calculus has a history stretching eons into the past. By its preservation of gastronomic comestibles, dental calculus endures long after its mortal owner has died, providing an historic chronicle of long-past dietary intakes.

The build-up of microorganisms and food debris along the tooth crown that eventually calcifies through a complex process of mineralisation provides archaeologists and anthropologists with evidence of past and present human diets. The insights into the lifestyles that can be gleaned from the detritus embedded in dental calculus is astonishing. The indisputable evidence of the composition and contents of dental tartar reveals much about the environment from which food is procured. ${ }^{1}$ The composition of human saliva provides a canvas upon which the food intake is encased in calculus. ${ }^{2}$ Ecological dietary differences between Neandertals from continental Europe and the Mediterranean region of Southern Europe and the Near East have been discerned. ${ }^{3,4}$

Moreover, the composition of dental calculus not only records food intake, but also the composition of the environment that provided the food. The incorporation of phytoliths in dental tartar provides evidence of the ingestion of fossil plants, indicative of ancient environments. ${ }^{5}$

The analysis of dental calculus provides micro-botanical evidence for the spread of cereal use during the Mesolithic-Neolithic transition in South Eastern Europe. ${ }^{6}$ Investigating plant micro-remains embedded in dental calculus of the Phoenician inhabitants of Motya (Sicily, Italy) reveals consumption. ${ }^{7}$

The health status and paleo diet of Mesolithic inhabitants of Motola, Sweden are revealed in a report by Norström E et al. ${ }^{8}$

Details of oral stress and palaeodietary changes among huntergatherers from the Negro River, Northern Patagonia, Argentina are detailed by Flensborg G et al. ${ }^{9}$

Remarkable ethnobotanical evidence has been gleaned from dental calculus of the Roman Imperial community inhabitants of the Ager Curensis. $^{10}$

Evidence of ferns as healing plants in medieval Mallorca, Spain has been revealed by analysis of dental tartar containing fern material. ${ }^{11}$
The revelation of the ingestion of ancient alkaloids by detection of nicotine in calculus samples from the Americas has been reported by Eerkens J W et al. ${ }^{12}$

Moreover, direct evidence of fish and plant consumption in the Mesolithic Mediterranean has been provided by dental calculus and contained isotopes. ${ }^{13}$

The calcified biofilm of dental calculus as a cause of periodontitis has been explored by Akcali A et al. ${ }^{14}$

Insights into the inhabitants of the Copper-Bronze Age in central Italy have been revealed by plant micro-remains in dental calculus from Grotta dello Scoglietto (Southern Tuscany, Italy). ${ }^{15}$

The revelations that can be conjured from the dental debris that dental hygienists and periodontists are dedicated to delete provides an historical review of past and present diets. Our dietary preferences can be permanently embedded in our mouths for future odontologists to discern.

\section{References}

1. Lieverse A R. Diet and the aetiology of dental calculus. Int J Osteoarchaeol 1999; 9: 219-232

2. Tiwari M. Science behind human saliva. J Nat Sci Bio/ Med 2011; 2: 53-58.

3. Droke J L, Schmidt C W, Williams F L et al. Regional variability in diet between Northern European and Mediterranean Neandertals: Evidence from dental microware texture analysis. In Schmidt C W, Watson J T (eds). Dental wear in evolutionary and biocultural contexts. 1st edition. pp 225-241. San Diego: Elsevier Science Publishing Co Inc., 2020.

4. Droke J L. Neandertal Dental Microwear Texture Analysis: A Bioarcheological Approach. Indianapolis (IN): University of Indianapolis, 2017. Available at: https://uindy. hykucommons.org/downloads/b46e9e40-b0bc-433c-89a1-d8c4d00ad453?locale=en (accessed May 2021)

5. Weyrich L S, Dobney K, Cooper A. Ancient DNA Analysis of dental calculus. J Hum Evol 2015; 79: 119-124.

6. Jovanović J, Power R C, de Becdelièvre C et al. Microbotanical evidence for the spread of cereal use during the Mesolithic-Neolithic transition in the Southeastern Europe (Danube Gorges): Data from dental calculus analysis. J Archaeol Sci 2020; 125: 105288.

7. D’Agostino A, Canini A, Di Marco G, Nigro L, Spagnoli F, Gismondi A. Investigating plant micro-remains embedded in dental calculus of the Phoenician inhabitants of Motya (Sicily, Italy). Plants (Basel) 2020; 9: 1395.

8. Norström E, Gustavsson R, Molin F, Gummesson S. Micro-fossil analysis of Mesolithic human dental calculus, Motala, Sweden - Indications of health status and paleo-diet. J Archaeol Sci Rep 2019; 26: doi 10.1016/j.jasrep.2019.05.031.

9. Flensborg G, Serna A, Prates L. Oral stress and paleodiet change among hunter-gatherers from Negro River (northern Patagonia, Argentina) during the late Holocene. Int $J$ Osteoarchaeol 2019; 29: 1060-1071.

10. D'Agostino A, Gismondi A, Di Marco G et al. Lifestyle of Roman Imperial community: enthnobotanical evidence from dental calculus of the Ager Curensis inhabitants. J Ethnobiol Ethnomed 2019; 15: 62. doi:10.1186/s13002-019-0334-z.

11. Fiorin E, Sáez L, Malgosa A. Ferns as healing plants in medieval Mallorca, Spain? Evidence from human dental calculus. Int J Osteoarchaeol 2018; 29: 82-90.

12. Eerkens J W, Tushingham S, Brownstein K J et al. Dental calculus as a source of ancient alkaloids: Detection of nicotine by LC-MS in calculus samples from the Americas. J Archaeol Sci Rep 2018; 18: 509-515.

13. Cristiani E, Radini A, Borić D et al. Dental calculus and isotopes provide direct evidence of fish and plant consumption in Mesolithic Mediterranean. Sci Rep 2018; 8: 8147. doi.10.1038/s41598-018-26045-9.

14. Akcali A, Lang N P. Dental calculus: the calcified biofilm and its role in disease development. Periodontol 2000 2018; 76: 109-115.

15. Lippi M M, Pisaneschi L, Sarti L et al. Insights into the inhabitants of the Copper-Bronze Age in Central Italy: Plant microremains in dental calculus from Grotta dello Scoglietto (Southern Tuscany, Italy). J Archaeol Sci Rep 2017; 15: 30-39.

\title{
BDA AGM
}

The Wessex Branch AGM will take place online on Thursday 10 June 2021 at 19:30.

Please ensure you register your interest in attending at www.bda.org/bse in order to receive the link to access the AGM or email branchsectionevents@bda.org. 